\title{
Location of tumour necrosis factor $\alpha$ by immunohistochemistry in chronic inflammatory bowel disease
}

\author{
S H Murch, C P Braegger, J A Walker-Smith, T T MacDonald
}

\begin{abstract}
This study determined the location and tissue density of cells immunoreactive for tumour necrosis factor $\alpha$ (TNF $\alpha$ ) in intestinal specimens from 24 patients with chronic inflammatory bowel disease (15 with Crohn's disease, nine with ulcerative colitis) and 11 controls. There was significantly increased density of TNF $\alpha$ immunoreactive cells in the lamina propria of both ulcerative colitis and Crohn's disease specimens, although the distribution of these cells differed in the two conditions. In ulcerative colitis most of the TNF $\alpha$ immunoreactivity was seen in the subepithelial macrophages, with comparatively less in the deep lamina propria, while in Crohn's disease immunoreactive cells were distributed evenly throughout the lamina propria. Increased submucosal immunoreactivity was found only in Crohn's disease, in which TNF $\alpha$ positive macrophages tended to cluster around arterioles and venules, often infiltrating and disrupting vascular endothelium. It is suggested that this degree of TNF $\alpha$ production probably contributes significantly to the pathogenesis of both Crohn's disease and ulcerative colitis, by impairing the integrity of epithelial and endothelial membranes, increasing inflammatory cell recruitment, and by prothrombotic effects on the vascular endothelium.

(Gut 1993; 34: 1705-1709)
\end{abstract}

Activated macrophages are prominent in the inflammatory infiltrate in both ulcerative colitis and Crohn's disease. ${ }^{1-7}$ There is known to be local production of the macrophage derived cytokines interleukin-1 (IL-1) and tumour necrosis factor $\alpha$ (TNF $\alpha),{ }^{8-10}$ in inflammatory bowel disease, and these may be detected at raised concentrations in the serum in active disease." Serum concentrations of interleukin-6 are also raised in active Crohn's disease but surprisingly not in ulcerative colitis. ${ }^{12}$ The importance of macrophage products as agents of intestinal inflammation has been shown in animal studies by the induction of intestinal necrosis by TNF $\alpha$ and platelet activating factor ${ }^{13}$ and the protective effect of IL-1 blockade in immune complex colitis. ${ }^{14}$ In previous studies of the possible role of TNF $\alpha$ in inflammatory bowel disease we have shown that much higher concentrations are found in the stools during relapse $^{\text {is }}$ (up to 5-10 $\mu \mathrm{g}$ TNF $\alpha / g$ ) than in serum, thus implying high concentrations in inflamed mucosa. If such high concentration mucosal production does occur, it is probable that specific treatment to reduce TNF $\alpha$ production will be of clinical benefit, and it is therefore important that the extent of local production is assessed more directly. In this study we have used immunohistochemistry to determine the distribution and density of TNF $\alpha$ containing cells, in the mucosa and submucosa of patients with chronic inflammatory bowel disease.

\section{Methods}

\section{PATIENTS}

Fifteen surgically resected specimens from patients with Crohn's disease were studied. Four specimens were from the jejunum and 11 from terminal ileum or ascending colon. Twelve of these patients were receiving corticosteroid treatment and three elemental diet at the time of surgery. Nine further specimens, including two colonoscopic biopsy specimens, were obtained from patients with ulcerative colitis, all of whom were receiving steroid treatment. The diagnosis of Crohn's disease or ulcerative colitis had previously been made on the basis of repeated colonoscopy, histological tests, and contrast radiography, and all specimens showed histological evidence of inflammation. The Table gives the clinical details of these patients and treatments received. Six of 11 control specimens were resected from adults (aged 18-64), whose

Clinical details of patients studied

\begin{tabular}{|c|c|c|c|c|c|c|c|}
\hline & \multirow[b]{2}{*}{ Age } & \multirow[b]{2}{*}{ Sex } & \multicolumn{2}{|c|}{ Activity indices } & \multicolumn{2}{|c|}{ Treatment } & \multirow[b]{2}{*}{ Location } \\
\hline & & & $\begin{array}{l}\text { ESR } \\
\text { ( } m m \text { in } \\
\text { first hour) }\end{array}$ & $\begin{array}{l}\text { CRP } \\
(m g / d l)\end{array}$ & $\begin{array}{l}\text { Steroid } \\
(m g / \\
\mathrm{kg})\end{array}$ & $A S A$ & \\
\hline \multicolumn{8}{|c|}{ Crohn's disease } \\
\hline 1 & 11 & $\mathbf{F}$ & 35 & 45 & $\mathbf{E}$ & - & Colon \\
\hline 2 & 11 & $M$ & 12 & 30 & $0 \cdot 2$ & + & Colon \\
\hline 3 & 13 & $\mathrm{~F}$ & 18 & 26 & 0.6 & + & Colon \\
\hline 4 & 11 & M & 70 & 115 & $\mathbf{E}$ & - & Ileum \\
\hline 5 & 14 & $\mathrm{~F}$ & 45 & 35 & 1.6 & + & Colon \\
\hline 6 & 14 & M & 26 & 34 & 0.4 & + & Colon \\
\hline 7 & 14 & M & 23 & 32 & 0.6 & - & Jejunum \\
\hline 8 & 16 & $\mathbf{F}$ & 20 & 6 & $\mathbf{E}$ & - & Jejunum \\
\hline 9 & 14 & M & 20 & 5 & $0 \cdot 8$ & - & Jejunum \\
\hline 10 & 17 & $M$ & 35 & 40 & E & - & Jejunum \\
\hline 11 & 9 & $\mathrm{~F}$ & 42 & 28 & $0 \cdot 3$ & - & Colon \\
\hline 12 & 16 & M & 21 & 36 & $1 \cdot 0$ & + & Ileum \\
\hline 13 & 13 & $\mathrm{~F}$ & 22 & 14 & 0.75 & + & Colon \\
\hline 14 & 14 & $M$ & 24 & 80 & 0.7 & + & Ileum \\
\hline 15 & 13 & $M$ & 35 & 42 & $1 \cdot 0$ & + & Ileum \\
\hline \multicolumn{8}{|c|}{ Ulcerative colitis } \\
\hline 1 & 2 & $\mathrm{~F}$ & 18 & 14 & $1 \cdot 2$ & + & Colon \\
\hline 2 & 13 & M & 35 & 10 & $0 \cdot 2$ & - & Colon \\
\hline 3 & 11 & $\mathrm{~F}$ & 45 & 40 & $0 \cdot 3$ & - & Colon \\
\hline 4 & 4 & M & 30 & 23 & $1 \cdot 0$ & + & Colon \\
\hline 5 & 11 & $\mathbf{M}$ & 56 & 56 & 0.6 & + & Colon \\
\hline 6 & 11 & $\mathrm{~F}$ & 25 & 5 & $0 \cdot 2$ & + & Rectum \\
\hline 7 & 13 & M & 49 & 23 & 1.5 & + & Colon \\
\hline 8 & 10 & $\mathbf{F}$ & 10 & 5 & 0.4 & + & Colon \\
\hline 9 & 0 & $\mathrm{~F}$ & 40 & 18 & 0.5 & + & Colon \\
\hline
\end{tabular}

E = Elemental diet $;$ steroid = prednisolone dose $(\mathrm{mg} / \mathrm{kg} /$ day); ASA = treatment with aminosalicylic acid (sulphasalazine or mesalazine); ESR = etythrocyte sedimentation rate; $\mathrm{CRP}=\mathrm{C}$ reactive protein 
indications for surgery included polyposis, chronic constipation, and carcinoma (two specimens were of terminal ileum, the rest colonic; all were histologically normal). The other five were histologically normal colonoscopic biopsy specimens taken from children investigated for abdominal pain. All biopsy specimens included muscularis mucosae; however only one contained sufficient submucosa for analysis of submucosal staining. Specimens were frozen in liquid nitrogen and stored at $-70^{\circ} \mathrm{C}$ until analysis, when sections cut at $7 \mu \mathrm{m}$ were applied to poly-l-lysine coated microscope slides and fixed in acetone before immunostaining.

\section{ANTIBODIES USED}

CB0006, an IgG1 $\varkappa$ purified mouse monoclonal antibody to human TNF $\alpha$ (a kind gift from Celltech Ltd, UK) was used throughout (dilution $1 / 100$ ). This antibody, which neutralises TNF $\alpha$ cytotoxicity on L929 cells and blocks TNF $\alpha$ induced MHC class I expression has been given therapeutically to humans suffering from septic shock, ${ }^{16}$ and is used to assay TNF $\alpha$ by enzyme linked immunosorbent assay (ELISA). ${ }^{17}$ It displays no cross reactivity with TNF $\beta$, interleukin-1 or interleukin-6 in ELISA or cold competition assay. ${ }^{14}$ Monoclonal antibodies to HLA-DR (1/100, Dako Ltd, Slough), CD25 (1/100 Dako), and CD3 (UCHT1, an undiluted supernatant) were used to stain serial sections. Control slides were stained with either TRIS buffered saline or an isotype matched monoclonal antibody (anti-cytokeratin, 1/100, Dako). After incubation with primary antibody for one hour at room temperature, staining was developed using the alkaline phosphatase antialkaline phosphatase (APAAP) technique with fast red substrate, as previously described. ${ }^{18}$ determined by point counting with a Lennox graticule, in tissue from normal controls and patients with Crohn's disease or ulcerative colitis $(U C)$ in $(A)$ subepithelial lamina propria, $(B)$ deep lamina propria, and $(C)$ submucosa. The filled squares were biopsy specimens and the open squares surgically resected. Among the Crohn's disease specimens, the open circles represent jejunal tissue, the diamonds terminal ileum, and the squares ascending colon.
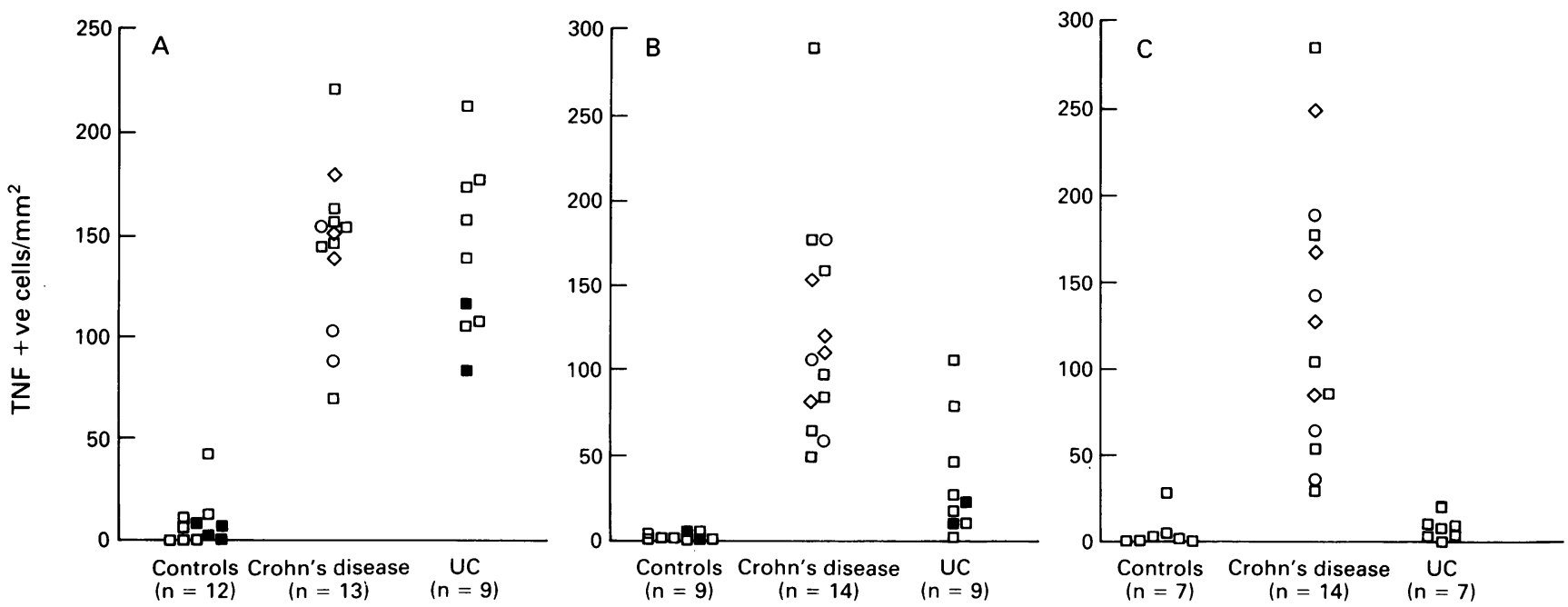

heterogeneous mucosal staining, with predominant subepithelial immunoreactivity, we subdivided the lamina propria arbitrarily into subepithelial (within one high power field of the epithelium) and deep (within one high power field of the muscularis mucosa). We excluded graticule points overlying the crypts from the initial count and subtracted the density of endogenously positive cells found in the matched control slides (median 29 cells $/ \mathrm{mm}^{2}$ (range 4-78) in disease specimens; median 3.5 cells $/ \mathrm{mm}^{2}$ (range $0-18$ ) in controls). Reproducibility of counts on blinded testing was within $10 \%$.

\section{STATISTICAL ANALYSIS}

As the resultant percentages within groups were not always normally distributed, group medians were calculated with $95 \%$ confidence intervals (derived by the Wilcoxon method) and comparison was made between groups using the two tailed Mann-Whitney U test.

\section{Results}

\section{LAMINA PROPRIA}

TNF $\alpha+$ cells were present in the lamina propria of six of the 11 normal controls, but these were few in number and largely confined to the subepithelial zone (median density 5.5 cells/ $\mathrm{mm}^{2}, 95 \%$ confidence intervals 1.6 to $20 \cdot 9$ ). Subepithelial TNF $\alpha+$ cell density was significantly increased compared with controls in both ulcerative colitis $\left(145.0\right.$ cells $/ \mathrm{mm}^{2}, 110.3$ to $184.5, \mathrm{p}<0.0001)$ and Crohn's disease $(148.0$ cells $/ \mathrm{mm}^{2}, 118.9$ to $162, \mathrm{p}<0.0001$ ) (see Figs $1 \mathrm{~A}$, 2). These large cells had the phenotypic appearance of macrophages, often showing extending processes (Fig 2), and similar cells on serial sections stained HLA-DR+, CD25+, CD3-. In addition the monoclonal antibody showed weak cross reactivity with epithelium.

The pattern of staining differed in the deep lamina propria, where the density of TNF $\alpha+$ cells was significantly greater in Crohn's disease $\left(118 \cdot 2\right.$ cells $/ \mathrm{mm}^{2}, 85 \cdot 1$ to 159$)$ than in ulcerative colitis $\left(28.8\right.$ cells $/ \mathrm{mm}^{2}, 10.9$ to $\left.64.3, \mathrm{p}<0.0005\right)$ or controls $\left(1.9\right.$ cells $/ \mathrm{mm}^{2}, 0$ to $3.8, \mathrm{p}<0.0001$ Fig 1B). TNF $\alpha+$ cells were still however higher positive graticule points overlying positively stained cells. ${ }^{19}$ As many specimens showed

The density of TNF $\alpha+$ cells within lamina propria and submucosa was determined with point counting technique, using a Lennox graticule over at least five randomly chosen high power fields within each region and counting as 

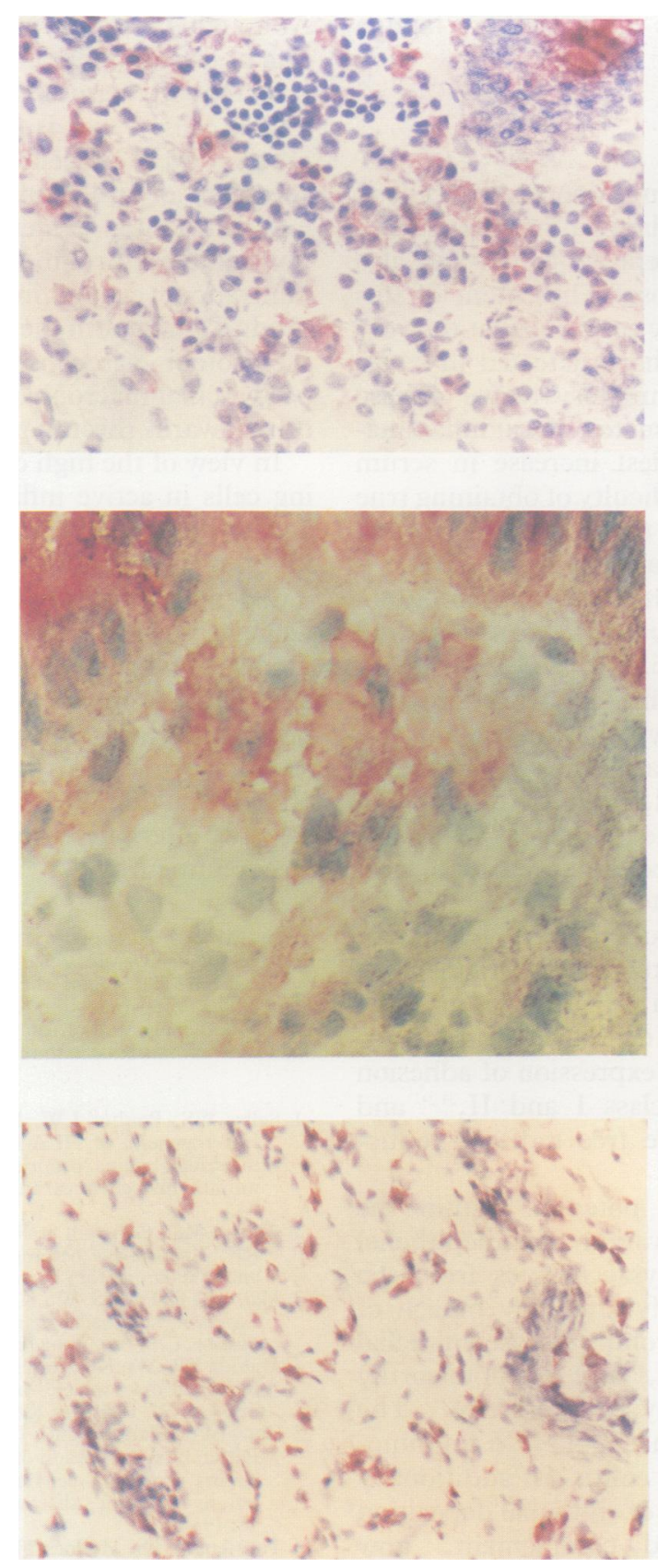

in ulcerative colitis than controls $(\mathrm{p}<0 \cdot 005)$. The morphology of TNF $\alpha+$ cells was more variable within the deeper lamina propria, particularly in Crohn's tissue (Fig 2). In addition to those with macrophage morphology, a population of smaller and more densely stained cells, could be identified. These cells were probably lymphocytes, as similar cells in serial sections were found to be $\mathrm{CD} 3+, \mathrm{CD} 25+$. In addition smaller numbers of TNF $\alpha+$ cells were identified on morphological grounds as polymorphonuclear leucocytes. TNF $\alpha+$ cells were also seen in Crohn's granulomas and in the germinal centres of lymphoid follicles: the second were large CD3 - cells and were presumably tingible body macrophages. No evidence of TNF $\alpha$ immunoreactivity was found elsewhere within the follicles.

\section{SUBMUCOSA}

Increased submucosal TNF $\alpha$ immunoreactivity
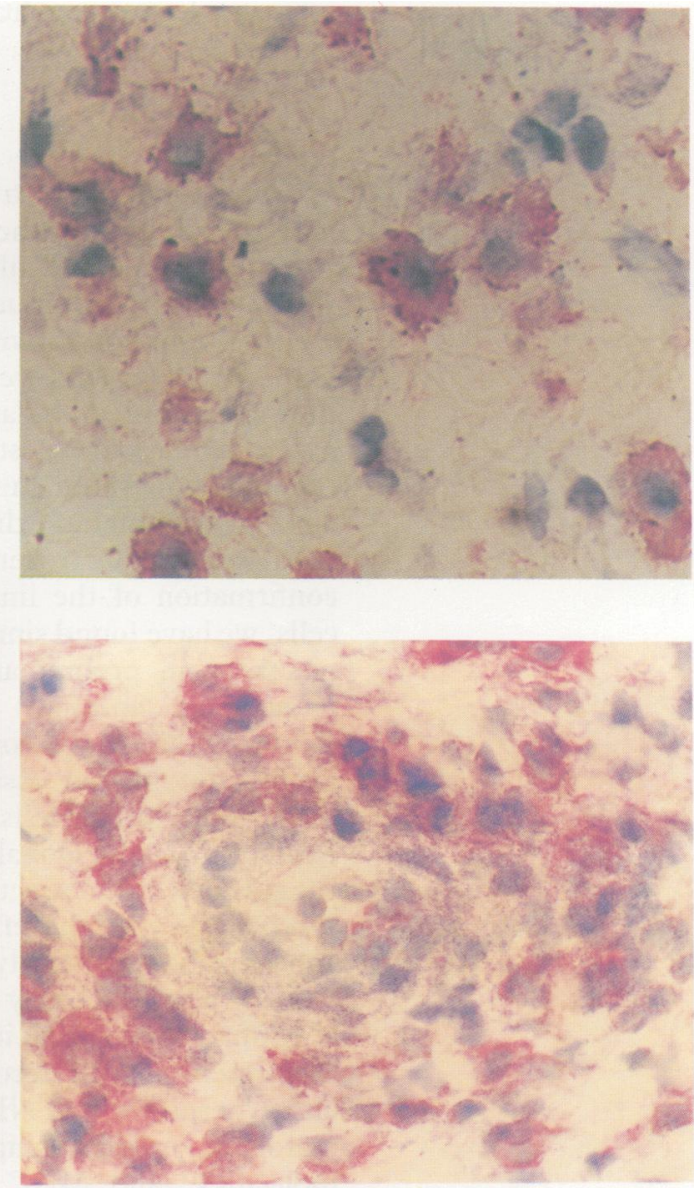

Figure 2: Tumour necrosis factor (TNF) $\alpha$ immunoreactive cells in chronic inflammatory bowel disease. Top left-lamina propria in Crohn's disease, showing a moderately dense infiltrate of red stained TNF $\alpha+$ cells (magnification $\times 200$ ); middle left - subepithelial TNF $\alpha+$ macrophages,

characteristic large cells with processes, in ulcerative colitis

(magnification $\times 400)$. The basal epithelial staining is a result of weak cross reactivity (also seen in the crypt in top left panel; top right-a dense infiltrate of TNF $\alpha+$ cells with macrophage morphology in Crohn's disease submucosa (magnification $\times 100)$; middle right - a higher power view of submucosal TNF $\alpha+$ macrophages in Crohn's disease (magnification $\times 400)$; bottom left - vasculopathy in Crohn's disease submucosa. The small arteriole in the centre is surrounded by TNF $\alpha+$ cells (magnification $\times 400)$.

was found in Crohn's disease but not in ulcerative colitis. TNF $\alpha+$ cell density was significantly increased in Crohn's tissue (median density $137 \cdot 0$ cells $/ \mathrm{mm}^{2}, 95 \%$ confidence intervals $94 \cdot 6$ to $190 \cdot 2)$ compared with both controls $(2 \cdot 30$ cells $/ \mathrm{mm}^{2}, 0$ to $15.5, \mathrm{p}<0.0002$ ) and ulcerative colitis specimens $\left(7 \cdot 0\right.$ cells $/ \mathrm{mm}^{2}, 2 \cdot 1$ to $14 \cdot 7$, $\mathrm{p}<0.0002$ ) (Figs 1C, 2). All of the Crohn's disease specimens showed evidence of transmural TNF $\alpha$ immunoreactivity, with increased numbers of TNF $\alpha+$ macrophages also found in muscularis externa and serosa.

There was evidence in all Crohn's specimens of accumulation of TNF $\alpha+$ cells, predominantly $\mathrm{CD} 3-$ cells with macrophage morphology, around submucosal and serosal blood vessels (Fig 2). This perivascular TNF $\alpha+$ accumulation was frequently associated with disruption of vascular smooth muscle and endothelium, and thrombosed or recanalised arteries were seen in eight of 15 specimens. Such perivascular concentration of TNF $\alpha+$ cells was not 
seen in ulcerative colitis or in Crohn's lamina propria.

\section{Discussion}

We have found TNF $\alpha$ immunoreactive cells at high density within the lamina propria in both Crohn's disease and ulcerative colitis and also within Crohn's submucosa. The extent of this TNF $\alpha$ immunoreactivity confirms that the very high concentrations we have detected in stools during relapse of inflammatory bowel disease give a more accurate estimate of local inflammation than does the modest increase in serum TNF $\alpha$. Although the difficulty of obtaining true serial sections in frozen tissue prevents formal confirmation of the lineage of these TNF $\alpha+$ cells, we have found similar patterns of immunoreactivity in preliminary work with a second monoclonal antibody 52 B 83 (also from Celltech), and have confirmed, with a reverse haemolytic plaque assay, that most mucosal TNF $\alpha$ secreting cells are macrophages (E J Breese, T T MacDonald, submitted data). We suggest that, whatever the lineage of the TNF $\alpha$ producing cells, the effects of such high local concentrations are likely to be adverse.

TNF $\alpha$ produced by subepithelial cells probably impairs epithelial integrity, ${ }^{20}$ particularly in the presence of interferon $\gamma .{ }^{2122}$ Interferon $\gamma$ may also synergise with TNF $\alpha$ in several proinflammatory ways, increasing expression of adhesion molecules ${ }^{23}$ and MHC class I and II, ${ }^{23}{ }^{24}$ and upregulating macrophage free radical production..$^{25}$

There is clearly the potential within the intestine for direct activation of subepithelial macrophages by lipopolysaccharides from the luminal flora, particularly after any breach of epithelial integrity. In Crohn's disease epithelial permeability is increased, ${ }^{26}$ and it is noteworthy that faecal diversion may be protective. ${ }^{27}$ The subepithelial predominance of TNF $\alpha$ immunoreactivity in ulcerative colitis is additionally concordant with findings of epithelial deposition of immunoglobulin and complement, ${ }^{6}$ now known to be related to expression of the $40 \mathrm{kD}$ putative autoantigen, ${ }^{28}$ as well as the subepithelial localisation of procollagen RNA production. ${ }^{29}$

The perivascular production of TNF $\alpha$ in Crohn's disease, also concordant with known patterns of complement deposition, ${ }^{30}$ is likely to be particularly damaging. It binds to high affinity endothelial cell surface receptors, ${ }^{31}$ and acts to increase inflammatory cell recruitment by upregulating expression of both adhesion molecules $^{32}$ and the chemotactic cytokine interleukin-8. ${ }^{33}$ The vascular effects of TNF $\alpha$ include increase in permeability ${ }^{20}{ }^{34}$ and powerful promotion of thrombosis ${ }^{35}$ by reduction of anticoagulant and activation of procoagulant mechanisms. It reduces the production of thrombomodulin, ${ }^{36}$ a natural anti-coagulant, which inactivates factor $\mathrm{Va}^{35}{ }^{37}$ and increases synthesis of plasminogen activator inhibitor-1. ${ }^{38}$ TNF $\alpha$ additionally induces expression of the powerfully procoagulant tissue factor, ${ }^{39}$ released only at sites of endothelial damage ${ }^{40}$ where it activates the extrinsic limb of the coagulation cascade. ${ }^{+1}$
Although TNF $\alpha$ infusion causes general activation of procoagulant pathways, ${ }^{42}$ its action seems preferentially targeted towards dividing endothelial cells - that is, at sites of injury, where much lower concentrations will induce this spectrum of prothrombotic change. ${ }^{43}$ There is now substantial evidence that vascular disruption and focal thrombosis, related to macrophage infiltration, occurs in Crohn's disease. ${ }^{44}$ The production of both the procoagulant TNF $\alpha$ and the potent vasoconstrictor endothelin- $1^{45}$ by perivascular macrophages will contribute powerfully towards thrombosis in this situation.

In view of the high density of TNF $\alpha$ producing cells in active inflammatory bowel disease, and the well characterised effects of this cytokine, it is probable that TNF $\alpha$ makes an independent contribution to inflammatory tissue damage. If this can be confirmed in animal models of intestinal inflammation, clinical use of anti-TNF $\alpha$ monoclonal antibodies or therapeutic inhibition of its production by agents such as transforming growth factor $\beta,{ }^{46}$ interleukin$10^{47}$ or thalidomide ${ }^{48-50}$ may provide potent and selective alternatives to current immunosuppressive treatment.

Simon Murch is supported by Action Research, Christian Braegger by the Swiss National Fund, and Thomas MacDonald by the Wellcome Trust and the Crohn's in Childhood Research Association. We would like to thank Dr Sue Stephens for her advice in the preparation of this manuscript and Mr William advice in the preparation of this manuscript and Mr William
Shand for his assistance in the collection of the surgical specimens.

1 Selby WS, Poulter LW, Hobbs S, Jewell DP, Janossy G. Heterogeneity of HLA-DR-positive histiocytes in huma intestinal lamina propria: a combined histochemical and immunohistochemical analysis. F Clin Pathol 1983; 36: 379 84.

2 Allison MC, Cornwall S, Poulter LW, Dhillon AP, Pounder RE. Macrophage heterogeneity in normal colonic mucosa and in inflammatory bowel disease. Gut 1988; 29: 1531-8.

3 Mahida YR, Patel S, Wu K, Jewell DP. Interleukin 2 receptor expression by macrophages in chronic inflammatory bowel disease. Clin Exp Immunol 1988; 74: 382-6.

4 Mahida YR, Wu KC, Jewell DP. Respiratory burst activity of intestinal macrophages in normal and inflammatory bowe disease. Gut 1989; 30: 1362-70.

5 Choy MY, Walker-Smith JA, Williams CB, MacDonald TT Differential expression of $\mathrm{CD} 25$ (interleukin-2 receptor) on lamina propria $\mathrm{T}$ cells and macrophages in the intestina lesions in Crohn's disease and ulcerative colitis. Gut 1990 31: 1365-70

6 Halstensen TS, Mollnes TE, Garred P, Fausa O, Brandtzaeg $P$. Epithelial deposition of immunoglobulin $G 1$ and activated complement ( $\mathrm{C} 3 \mathrm{~b}$ and terminal complemen complex) in ulcerative colitis. Gastroenterology 1990; 98: 1264-71.

7 Malizia G, Calabrese A, Cottone $M$, Raimondo $M$ Trejdosiewicz LK, Smart CJ, et al. Expression of leukocyte adhesion molecules by mucosal mononuclear phagocytes in inflammatory bowel disease. Gastroenterology 1991; 100 $150-9$.

8 Pullman WE, Elsbury S, Kobayashi M, Hapel AJ, Doe WF Enhanced mucosal cytokine production in inflammator bowel disease. Gastroenterology 1992; 102: 529-37.

9 MacDonald TT, Hutchings P, Choy M-Y, Murch S, Cooke A. Tumour necrosis factor-alpha and interferon-gamma production measured at the single cell level in normal and inflamed human intestine. Clin Exp Immunol 1990; 81: 301-5.

10 Cappello M, Keshav S, Prince C, Jewell DP, Gordon S Detection of $m R N A a$ for macrophage products in inflammaDetection of mRNAa for macrophage products in inflamma-
tory bowel disease by in situ hybridisation. Gut 1992; 33: tory bow

11 Murch SH, Lamkin VA, Savage MO, Walker-Smith JA MacDonald TT. Serum concentrations of tumour necrosis factor $\alpha$ in childhood

12 Gross V, Andus T, Caesar I, Roth M, Schmölmerich J Evidence for continuous stimulation of interleukin-6 production in Crohn's disease. Gastroenterology 1992; 102 $514-9$.

13 Sun X-M, Hsueh W. Bowel necrosis mediated by tumou necrosis factor is mediated by platelet-activating factor. 7 Clin Invest 1988; 81: 1328-31.

14 Cominelli F, Nast CC, Duchini A, Lee M. Recombinan interleukin-l receptor antagonist blocks the proinflammatory activity of endogenous interleukin-1 in rabbit immune colitis. Gastroenterology 1992; 103: 65-71. 
15 Braegger CP, Nicholls S, Murch SH, Stephens S, MacDonald TT. Stool TNF as a marker of intestinal inflammation. Lancet 1992; 339: 89-91.

16 Exley AR, Cohen J, Buurman W, Owen R, Hanson G, Lumley $\mathrm{J}$, et al. Monoclonal antibody to TNF in severe septic shock. Lancet 1990; 335: 1275-6.

17 Engelberts I, Möller A, Schoen GJM, van der Linden CJ, Buurman WA. Evaluation of measurement of human TNF in plasma by ELISA. Lymphokine Cytokine Res 1991; 10: 69in $\mathrm{p}$.

18 Isaacson PG, Wright DH. Imunocytochemistry of lymphorecticular tumours. Immunocytochemistry. In: Polak JM,
van Noorden S, eds. Practical applications in pathology and biology. Bristol: John Wright, 1983: 249.

19 Lennox B. Observations on the accuracy of point counting including the description of a new graticule. F Clin Pathol 1975; 28: 99-103.

20 Mullin JM, Snock KV. Effect of tumor necrosis factor on epithelial tight junctions and transepithelial permeability. Cancer Res 1990; 50: 2172-6.

21 Deem RL, Shanahan F, Targan SR. Triggered human mucosal $T$ cells release tumour necrosis factor-alpha and interferon-gamma which kill human colonic epithelial cells. Clin Exp Immunol 1991; 83: 79-84.

22 Schiller J, Bittner G, Storer B, Willson JKV. Synergistic antitumor effects of tumor necrosis factor and $\gamma$-interferon on human colon carcinoma cell lines. Cancer Res 1987; 47: 2809-13.

23 Doukas J, Pober JS. IFN-gamma enhances endothelial activation induced by tumor necrosis factor but not IL-1. f Immunol 1990; 145: 1727-33.

24 Kvale D, Brandtzaeg P, Lovhaug D. Up-regulation of the expression of secretory component and HLA molecules in a
human colonic cell line by tumour necrosis factor- $\alpha$ and gamma interferon. Scand f Immunol 1988; 28: 351-7.

25 Ding A, Nathan CF, Stuehr DJ. Release of reactive nitrogen intermediates and reactive oxygen intermediates from mouse peritoneal macrophages: comparison of activating mouse peritoneal macrophages: comparison of activating cytokines and evidence for

26 Hollander D. Crohn's disease - a permeability disorder of the tight junction? Gut 1989; 29: 1621-4.

27 Rutgeerts P, Goboes K, Peeters M, Hiele M, Penninckx F, Aerts $R$, et al. Effect of faecal stream diversion on recurrence of Crohn's disease in the neoterminal ileum. Lancet 1991; 338: $771-4$

28 Halstensen TS, Das KM, Brandtzaeg P. Epithelial deposits of immunoglobulin $\mathrm{Gl}$ and activated complement colocalise with $M_{r} 40 \mathrm{kD}$ putative autoantigen in ulcerative colitis. Gastroenterology 1993; 34: 650-7.

29 Matthes H, Herbst H, Schuppan D, Stallmach A, Milani S, Stein $\mathrm{H}$, et al. Cellular localization of procollagen gene
transcripts in inflammatory bowel disease. Gastroenterology transcripts in infla

30 Halstensen TS, Mollnes TE, Brandtzaeg P. Persistent complement activation in submucosal blood vessels of active inflammatory bowel disease: immunohistochemical evidence. Gastroenterology 1989; 97: 10-9.

31 Nawroth P, Bank I, Handely D, Cassimeris J, Chess L, Stern D. Tumor necrosis factor/cachectin interacts with endothelial cell receptors to induce release of interleukin $1 . \mathcal{F} E x p$ Med 1986; 163: 1363-75.

32 Gamble JR, Smith WB, Vadas MA. TNF modulation of endothelial and neutrophil adhesion. In: Beutler B, ed. Tumor necrosis factors: the molecules and their emerging role in Tumor necrosts factors: the molecules and their emergi

33 Strieter RM, Kunkel SL, Showell HJ, et al. Endothelial expression of a neutrophil chemotactic factor by TNF $\alpha$, LPS and IL-1 $\beta$. Science 1989; 243: 1467.

34 Brett J, Gerlach H, Nawroth P, Steinberg S, Godman G, Stern $D$. Tumor necrosis factor/cachectin increases permeability of endothelial cell monolayers by a mechanism involving regulatory G proteins. F Exp Med 1989; 169: 1977-91.

35 Clauss M, Ryan J, Stern D. Modulation of endothelial cell hemostatic properties by TNF: insights into the role of endothelium in the host response to inflammatory stimuli. In: Beutler B, ed. Tumor necrosis factors: the molecules and their emerging role in medicine. New York: Raven Press, 1992: their emerg.

36 Moore K, Esmon C, Esmon N. Tumor necrosis factor leads to the internalization and degradation of thrombomodulin from the surface of bovine aortic endothelial cells in culture. Blood 1989; 73: 159-65.

37 Nawroth P, Stern D. Modulation of endothelial cell haemostatic properties by tumor necrosis factor. F Exp Med 1986; 163: 740-5.

38 Schleef R, Bevilacqua M, Sawdey M, Gimbrone M, Loskutoff D. Cytokine activation of vascular endothelium. Effects on tissue-type plasminogen activator and type 1 plasminogen tissue-type plasminogen activator and type 1 plasmin

39 Bevilacqua M, Pober J, Majeau G, Fiers W, Cotran R, Gimbrone $M$. Recombinant TNF induces procoagulan activity in endothelium. Proc Natl Acad Sci USA 1986; 83: 4533-7.

40 Ryan J, Brett J, Kisiel W, Stern D. Tumor necrosis factorinduced endothelial cell tissue factor is principally associated with the subendothelial matrix. Blood 1990; 82 (suppl 76) 361A.

41 Bach R, Nemerson Y, Konigsberg W. Purification and characterisation of bovine tissue factor. $\mathcal{F}$ Biol Chem 1981; 156: 8324-31.

42 van der Poll T, Buller HR, ten Cate H, Wortel CH, Bauer KA, van Deventer SJH, et al. Activation of coagulation after administration of tumor necrosis factor to normal subjects. N Englf Med 1990; 322: 1622-7.

43 Gerlach H, Liebermann H, Brett J, Bach R, Godman G, Stérn D. Growing/motile endothelium shows enhanced responsiveness to tumor necrosis factor/cachectin. $\mathcal{F}$ ExpMed 1989; 170: 913-31.

44 Wakefield AI, Dhillon AP, Rowles PM, Sawyerr AM, Pittilo RM, Lewis AAM, et al. Pathogenesis of Crohn's disease: multifocal gastrointestinal infarction. Lancet 1989; 334: 1057-62.

45 Murch SH, Braegger CP, Sessa WS, MacDonald TT. Increased endothelin immunoreactivity in Crohn's disease and ulcerative colitis. Lancet 1992; 339: 381-5.

46 Ding A, Nathan CF, Graycar J, Derynck R, Stuehr DJ, Srimal S. Macrophage deactivating factor and transforming growth factors- $\beta 1,-\beta 2$, and $-\beta 3$ inhibit induction of macrophage nitrogen oxide synthesis by IFN $-\gamma$. F Immunol 1990; 145: $940-4$.

47 Bogdan C, Vodovotz Y, Nathan C. Macrophage deactivation by interleukin 10. $₹$ Exp Med 1991; 174: 1549-55.

48 Sampaio EP, Sarno EN, Galilly R, Cohn ZA, Kaplan G. Thalidomide selectively inhibits tumor necrosis factor $\alpha$ production by stimulated human monocytes. 7 Exp Med 1991; 173: 699-703.

49 Vogelsgang GB, Farmer ER, Hess AD, Altamonte V, Beschorner WE, Jabs DA, et al. Thalidomide for the treatment of chronic graft-versus-host disease. $N E n g l f(M e d$ 1992; 326: 1055-8.

50 Larsson H. Treatment of severe colitis in Behcet's syndrome with Thalidomide (CG-217). F Int Med 1990; 228: 405-7. 